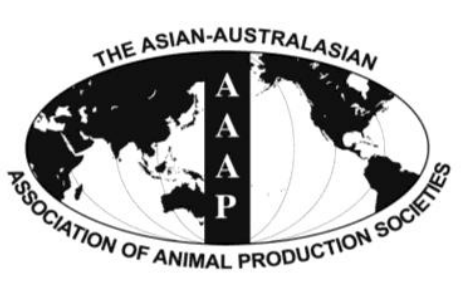

\title{
Ileal Digestibility of Amino Acids in Meat Meal and Soybean Meal Fed to Growing Pigs
}

\author{
C. Kong ${ }^{1}$, H. G. Kang ${ }^{1}$, B. G. Kim ${ }^{1}$, and K. H. Kim ${ }^{2,3}$ ** \\ ${ }^{1}$ Department of Animal Science and Technology, Konkuk University, Seoul 143-701, Korea
}

\begin{abstract}
The objective of this experiment was to determine the concentration and digestibility of crude protein $(\mathrm{CP})$ and amino acid (AA) in meat meal (MM), and to compare these values with the respective values in soybean meal (SBM). Six barrows (initial body weight $=66.9 \pm 3.8 \mathrm{~kg}$ ) surgically fitted with a T-cannula at the distal ileum were allotted to a replicated $3 \times 3$ balanced Latin square design with 3 diets and 3 periods. Two experimental diets containing test ingredients as the sole source of AA were prepared to estimate the apparent ileal digestibility (AID) for $\mathrm{CP}$ and AA by the direct method. An $\mathrm{N}$-free diet was also prepared to estimate basal endogenous losses of $\mathrm{CP}$ and AA. All experimental diets contained 5\% chromic oxide as an indigestible index. Each period consisted of a 5-d adaptation period and a 2-d of ileal digesta collection period. Ileal digesta samples were collected from 0900 to 1700 on d 6 and 7 of each period. The concentrations of CP, Lys, Met, and Trp in MM and SBM were analyzed to be 64.1, 3.5, 1.1 and 0.6, and 45.6, 2.8, 0.8, and $0.3 \%$, respectively. The AID of all AA except Gly in MM was less ( $\mathrm{p}<0.05)$ than in SBM. The AID of Lys, Met, and Trp in MM was estimated to be 56.0, 71.7, and 47.1\%, respectively. The SID of all AA in MM was less (p<0.05) than in SBM. The SID of Lys, Met, and Trp was 65.1, 79.2, and 78.5\%, respectively. In conclusion, the CP and AA contents in MM were greater than those in SBM whereas the ileal digestibility of all AA in MM was less than in SBM. (Key Words: Feedstuff, Standardized Ileal Digestibility, Meat Meal, Soybean Meal, Swine)
\end{abstract}

\section{INTRODUCTION}

An accurate formulation of a swine diet meeting amino acid (AA) requirements is important to improve swine production as well as to minimize the excretion of $\mathrm{N}$. Several types of ingredient have been used as major protein sources for swine feed formulation including plant and animal origin proteins (Jørgensen et al., 1984; Stein et al., 2001; Gottlob et al., 2006). It has been also shown that protein sources vary widely in terms of their ability to supply AA utilizable for protein synthesis for pigs (Stein et al., 2001). Thus, it is essential to estimate $\mathrm{N}$ and AA utilization. Among estimates for the digestibility of these

\footnotetext{
* Corresponding Author: K. H. Kim. Tel: +82-33-339-5726, Fax: +82-33-339-5732, E-mail: khhkim@ snu.ac.kr

${ }^{2}$ Department of Food and Animal Biotechnology, Seoul National University, Seoul 151-921, Korea.

${ }^{3}$ Institute of Green Bio Science and Technology, Seoul National University, Pyeongchang 232-916, Korea.

Submitted Mar. 26, 2014; Revised Apr. 26, 2014; Accepted Apr. 28, 2014
}

nutrients, ileal digestibility rather than total tract digestibility has been known to be more reliable to represent AA digestibility (Sauer and Ozimek, 1986). To attain ileal digestible AA contents in a diet or a feed ingredient, apparent ileal digestibility (AID) has been used, but it has been reported that AID does not account for the endogenous AA which is derived from animal body, and consequently, is underestimated especially when feeding pigs a low-protein diet (Mosenthin et al., 2000). To overcome this inaccuracy of AID estimate, the standardized ileal digestibility (SID) which is corrected for AID with basal endogenous losses (BEL) of AA, has been suggested for estimating the ileal digestibility of AA (Jondreville et al., 1995).

Meat meal (MM) is defined as the rendered product from mammal tissues, exclusive of blood, hair, hoof, horn, hide trimmings, manure, stomach and rumen contents (AAFCO, 2010) and is commonly included in swine diet as a protein source (Traylor et al., 2005). The SID for MM has been provided in NRC (2012). However, there are large 
variations in crude protein $(\mathrm{CP})$ and AA contents in $\mathrm{MM}$ as well as their digestible contents. Moreover, there is a scarcity of data on the digestibility of CP and AA in MM for pigs. Therefore, the objective of the present study was to determine the SID for CP and AA in MM fed to growingfinishing pigs and to compare the digestibility values with those in soybean meal (SBM).

\section{MATERIALS AND METHODS}

All the experimental procedures used in the current study were approved by the National Institute of Animal Science Institutional Animal Care and Use Committee.

\section{Animals and experimental design}

Six crossbred barrows with an average initial body weight $(\mathrm{BW})$ of $66.9 \mathrm{~kg}$ (standard deviation = 3.8) fitted with a T-cannula at the distal ileum using surgery procedures adapted from Stein et al. (1998) were used to determine the $\mathrm{CP}$ and AA digestibility in SBM and MM (Table 1). Pigs were individually housed in metabolism crates $(0.48 \times 1.49 \mathrm{~m})$ in an environmentally controlled room

Table 1. Analyzed nutrient composition of soybean meal and meat meal, as-is basis

\begin{tabular}{|c|c|c|}
\hline Item & Soybean meal (\%) & Meat meal (\%) \\
\hline \multicolumn{3}{|l|}{ Ingredient } \\
\hline Dry matter & 87.7 & 96.5 \\
\hline Ether extract & 1.4 & 8.5 \\
\hline Ash & 5.9 & 22.3 \\
\hline Calcium & 0.16 & 6.83 \\
\hline Phosphorus & 0.64 & 3.76 \\
\hline Crude protein & 45.6 & 64.1 \\
\hline \multicolumn{3}{|c|}{ Indispensable amino acid } \\
\hline Arg & 3.2 & 5.1 \\
\hline His & 1.7 & 1.8 \\
\hline Ile & 2.0 & 1.8 \\
\hline Leu & 3.6 & 4.0 \\
\hline Lys & 2.8 & 3.5 \\
\hline Met & 0.8 & 1.1 \\
\hline Phe & 2.4 & 2.2 \\
\hline Thr & 1.9 & 2.0 \\
\hline $\operatorname{Trp}$ & 0.3 & 0.6 \\
\hline Val & 2.0 & 2.6 \\
\hline \multicolumn{3}{|c|}{ Dispensable amino acid } \\
\hline Ala & 2.0 & 5.2 \\
\hline Asp & 5.0 & 5.1 \\
\hline Cys & 1.0 & 0.6 \\
\hline Glu & 7.5 & 8.1 \\
\hline Gly & 1.9 & 10.5 \\
\hline Pro & 2.5 & 6.7 \\
\hline Ser & 2.5 & 2.6 \\
\hline Tyr & 1.6 & 1.5 \\
\hline
\end{tabular}

at the National Institute of Animal Science, Suwon, Republic of Korea. The 6 barrows were assigned to 3 dietary treatments in a replicated $3 \times 3$ Latin square design involving 3 periods per square. Potential carryover effects were balanced using a program developed by Kim and Stein (2009).

\section{Diets and feeding}

Two experimental diets were prepared to contain SBM or MM as the sole source of CP and AA (Tables 2 and 3). An $\mathrm{N}$-free diet was also prepared mainly based on cornstarch and sucrose to estimate the basal endogenous AA losses. Chromic oxide was included at $0.5 \%$ as an indigestible index for the calculation of digestibility. Vitamins and trace minerals were included in all diets to meet or exceed nutrient requirement estimates (NRC, 1998).

Pigs were allowed to consume diets 2 times a day at 0900 and 1700 and daily feed allowance was 3 times the estimated maintenance requirement for energy (i.e., 106 $\mathrm{kcal}$ of $\mathrm{ME} / \mathrm{kg} \mathrm{BW}^{0.75}$ ). Water was freely available through a nipple at all times.

\section{Data recording and sample collection}

Pigs were weighed at the beginning of each period, and the amount of feed provided each day were recorded. Each period consisted of a 5-d acclimation period to the feed and a 2-d ileal collection period. Ileal samples were collected

Table 2. Ingredient composition of the experimental diets, as-fed basis

\begin{tabular}{lccc}
\hline & \multicolumn{3}{c}{ Experimental diet (\%) } \\
\cline { 2 - 4 } Item & $\begin{array}{c}\text { Soybean } \\
\text { meal }\end{array}$ & $\begin{array}{l}\text { Meat } \\
\text { meal }\end{array}$ & N-Free \\
\hline Ingredient & & & \\
Soybean meal & 35.0 & - & - \\
Meat meal & - & 25.0 & - \\
Corn starch & 39.0 & 53.7 & 68.6 \\
Sucrose & 20.0 & 20.0 & 20.0 \\
Soybean oil & 3.0 & - & 4.0 \\
Cellulose & - & - & 3.5 \\
Ground limestone & 0.7 & - & 0.8 \\
Dicalcium phosphate & 1.0 & - & 1.3 \\
Potassium carbonate & - & - & 0.4 \\
Magnesium oxide & - & - & 0.1 \\
Salt & 0.4 & 0.4 & 0.4 \\
Vitamin-mineral premix ${ }^{1}$ & 0.4 & 0.4 & 0.4 \\
Chromic oxide & 0.5 & 0.5 & 0.5 \\
\hline
\end{tabular}

${ }^{1}$ Provided the following quantities per $\mathrm{kg}$ of complete diet: vitamin A, 20,000 IU; vitamin $\mathrm{D}_{3}, 3,200 \mathrm{IU}$; vitamin E, $40 \mathrm{IU}$; vitamin $\mathrm{K}, 4.0 \mathrm{mg}$; thiamin, $3.9 \mathrm{mg}$; riboflavin, $8.0 \mathrm{mg}$; pyridoxine, $3.9 \mathrm{mg}$; vitamin $\mathrm{B}_{12}$, $0.05 \mathrm{mg}$; pantothenic acid, $30.0 \mathrm{mg}$; folic acid, $0.88 \mathrm{mg}$; niacin, $50 \mathrm{mg}$; biotin, $0.05 \mathrm{mg}$; $\mathrm{Cu}, 20 \mathrm{mg}$ as copper sulfate; $\mathrm{Fe}, 214 \mathrm{mg}$ as iron sulfate; I, $4.0 \mathrm{mg}$ as potassium iodate; $\mathrm{Mn}, 100 \mathrm{mg}$ as manganese sulfate; $\mathrm{Se}, 0.3$ $\mathrm{mg}$ as sodium selenite; $\mathrm{Zn}, 251 \mathrm{mg}$ as zinc oxide; and butylated hydroxytoluene, $40 \mathrm{mg}$. 
Table 3. Analyzed nutrient composition of experimental diets, asfed basis

\begin{tabular}{|c|c|c|c|}
\hline \multirow{2}{*}{ Item } & \multicolumn{3}{|c|}{ Experimental diet $(\%)$} \\
\hline & Soybean meal & Meat meal & $\mathrm{N}$-free \\
\hline \multicolumn{4}{|l|}{ Ingredient } \\
\hline Dry matter & 90.9 & 91.4 & 90.3 \\
\hline Ether extract & 3.3 & 2.2 & 3.1 \\
\hline Ash & 4.5 & 5.9 & 3.7 \\
\hline Crude protein & 16.9 & 16.3 & 0.3 \\
\hline \multicolumn{4}{|c|}{ Indispensable amino acid } \\
\hline $\operatorname{Arg}$ & 1.1 & 1.2 & ND \\
\hline His & 0.6 & 0.5 & ND \\
\hline Ile & 0.7 & 0.4 & ND \\
\hline Leu & 1.3 & 0.9 & ND \\
\hline Lys & 1.0 & 0.8 & ND \\
\hline Met & 0.3 & 0.3 & ND \\
\hline Phe & 0.8 & 0.5 & ND \\
\hline Thr & 0.7 & 0.5 & ND \\
\hline $\operatorname{Trp}$ & 0.2 & 0.1 & ND \\
\hline Val & 0.7 & 0.6 & ND \\
\hline \multicolumn{4}{|c|}{ Dispensable amino acid } \\
\hline Ala & 0.7 & 1.3 & ND \\
\hline Asp & 2.0 & 1.3 & ND \\
\hline Cys & 0.3 & 0.2 & ND \\
\hline Glu & 3.0 & 2.0 & ND \\
\hline Gly & 0.7 & 2.5 & ND \\
\hline Pro & 0.8 & 1.7 & ND \\
\hline Ser & 0.9 & 0.6 & ND \\
\hline Tyr & 0.5 & 0.3 & ND \\
\hline
\end{tabular}

ND, not detectable.

from T-cannula for $8 \mathrm{~h}$ on $\mathrm{d} 6$ and 7 according to the procedure described by Kim et al. (2012). Briefly, a plastic bag was attached to the cannula barrel using a wire embedded in the bag. The plastic bag was inspected at 30min intervals and changed as needed. Immediately after digesta collection, the sample was frozen to prevent bacterial degradation of AA in the digesta. At the end of each period, animals were fasted and a new experimental diet was provided on the next morning meal.

\section{Chemical analyses}

The frozen ileal samples were thawed at room temperature, pooled for each pig within each period and subsampled. The digesta samples were freeze-dried and finely ground prior to chemical analysis. All samples were analyzed for dry matter (DM) (method 930.15; AOAC, 2005) by drying samples at $135^{\circ} \mathrm{C}$ in a drying oven (FEPO-150; Dongseo Science Co. Ltd., Seongnam, Korea) for $2 \mathrm{~h}$. Nitrogen for $\mathrm{CP}$ content $(\mathrm{N} \times 6.25)$ was analyzed by the Kjeldahl method (Kjeltec 1035; Foss, Hillerod, Denmark). Samples for AA analysis were prepared using a 24-h hydrolysis in $6 \mathrm{~N} \mathrm{HCl}$ at $110^{\circ} \mathrm{C}$ under an atmosphere of $\mathrm{N}$.
For Met and Cys, performic acid oxidation was done prior to acid hydrolysis. Samples for Trp analysis were hydrolyzed using barium hydroxide. Amino acids in hydrolysates were determined by HPLC after post-column derivatization (method 982.30 E [a, b, c], AOAC, 2005). Chromium was analyzed using the atomic absorption spectrophotometry (IRIS Intre PID II XSP, Thermo, Waltham, MA, USA). A $10 \mathrm{~g}$ of sample was put into the crucible. One $\mathrm{ml}$ of 3-potassium phosphate solution was added and mixed thoroughly using a glass rod. The solution was burned in the electric furnace at $800^{\circ} \mathrm{C}$. After freezing it, the residue in the crucible was diluted using distilled water. The solution was massed up to $250 \mathrm{~mL}$ in a flask and left it overnight. On the next day, the liquid was filtered to be used as a test solution.

\section{Calculation and statistical analyses}

The AID for CP and AA in SBM and MM was estimated by the direct method described by Stein et al. (2007). Because the test ingredient was the only source contributing $\mathrm{CP}$ and $\mathrm{AA}$ in each diet, the estimated AID of these nutrients in the experimental diet also represented the respective digestibility for each ingredient. The AID, SID, and BEL were calculated using the following equations (adapted from Stein et al., 2007):

$$
\begin{aligned}
& \text { AID }(\%) \\
& =\left[1-\left(\mathrm{AA}_{\text {digesta }} \div \mathrm{AA}_{\text {diet }}\right) \times\left(\mathrm{Cr}_{\text {diet }} \div \mathrm{Cr}_{\text {digesta }}\right)\right] \times 100 \\
& \mathrm{IAA}_{\text {end }}=\left(\mathrm{AA}_{\text {digesta }}\right) \times\left(\mathrm{Cr}_{\text {diet }} \div \mathrm{Cr}_{\text {digesta }}\right) \\
& \text { SID }(\%)=\mathrm{AID}+\left(\mathrm{IAA}_{\text {end }} \div \mathrm{AA}_{\text {diet }}\right) \times 100
\end{aligned}
$$

where $\mathrm{AA}_{\text {diet }}$ and $\mathrm{AA}_{\text {digesta }}$ are the $\mathrm{AA}$ concentration in the diet and ileal digesta, respectively ( $\mathrm{g} / \mathrm{kg}$ of $\mathrm{DM})$; and $\mathrm{Cr}_{\text {diet }}$ and $\mathrm{Cr}_{\text {digesta }}$ are the chromium concentration of the diet and ileal digesta, respectively $(\mathrm{g} / \mathrm{kg}$ of $\mathrm{DM})$; $\mathrm{IAA}_{\text {end }}$ is the BEL of an AA ( $\mathrm{g} / \mathrm{kg}$ of DMI). The AID and SID of CP was also calculated as AA in equation (1) and (3) replaced by CP.

The experimental data were statistically analyzed using MIXED procedures of SAS (SAS Inst. Inc., Cary, NC, USA). The independent variables in the model included diet as a fixed effect and animal and period as random effects. Digestibility was response variable and each animal was considered as an experimental unit. The alpha level used for the determination of statistical differences was set at 0.05 .

\section{RESULTS AND DISCUSSION}

\section{Nutrient composition of test ingredients}

The analyzed nutrient composition of SBM and MM used in the current study is provided in Table 1 . The results for SBM showed that the proximate analyses and the 
analyzed AA composition were comparable with the values reported in NRC (2012) whereas the respective composition of MM was greater in $\mathrm{CP}$ and less in ether extract than the values reported in NRC (2012). The difference in the chemical composition of MM between the current study and NRC (2012) may be attributed to the effects of location and source of MM (Wang and Parsons, 1998). Meat meal and meat and bone meal (MBM) have been similarly defined except that MBM contains more bone and the $\mathrm{P}$ level is $4.0 \%$ or greater and the $\mathrm{Ca}$ level of both products is less than 2.2 times the $\mathrm{P}$ level (AAFCO, 2010). The concentration of $\mathrm{P}$ and $\mathrm{Ca}$ in $\mathrm{MM}$ used in the present experiment met the criterion for MM by AAFCO (2010). The ash content of MM used in the current study was analyzed to be $22.3 \%$ which is similar to the value for MM reported in NRC (2012) and less than that of MBM (32.0\%) which is due to the difference in bone contents between the 2 ingredients.

\section{Apparent and standardized ileal digestibility of amino acids}

The respective AID of AA in pigs for SBM and MM was 79.3 and $56.0 \%$ for Lys, 84.7 and $71.7 \%$ for Met, and 69.0 and $38.9 \%$ for Thr, respectively (Table 4). The AID of

Table 4. Apparent ileal digestibility of crude protein and amino acids in soybean meal and meat meal ${ }^{1}$

\begin{tabular}{|c|c|c|c|c|}
\hline \multirow[b]{2}{*}{ Item } & \multicolumn{2}{|c|}{ Test ingredient $(\%)$} & \multirow[b]{2}{*}{ SEM } & \multirow[b]{2}{*}{ p-value } \\
\hline & $\begin{array}{c}\text { Soybean } \\
\text { meal }\end{array}$ & $\begin{array}{l}\text { Meat } \\
\text { meal }\end{array}$ & & \\
\hline \multicolumn{5}{|l|}{ Ingredient } \\
\hline Crude protein & 72.9 & 46.9 & 3.0 & $<0.001$ \\
\hline \multicolumn{5}{|c|}{ Indispensable amino acid } \\
\hline Arg & 85.7 & 71.4 & 2.3 & 0.002 \\
\hline His & 39.7 & 4.3 & 3.4 & $<0.001$ \\
\hline Ile & 81.3 & 57.7 & 2.2 & $<0.001$ \\
\hline Leu & 80.8 & 61.1 & 2.0 & $<0.001$ \\
\hline Lys & 79.3 & 56.0 & 2.0 & $<0.001$ \\
\hline Met & 84.7 & 71.7 & 1.6 & $<0.001$ \\
\hline Phe & 82.2 & 64.2 & 1.9 & $<0.001$ \\
\hline Thr & 69.0 & 38.9 & 2.6 & $<0.001$ \\
\hline $\operatorname{Trp}$ & 78.4 & 47.1 & 2.8 & 0.002 \\
\hline Val & 76.0 & 55.5 & 2.4 & $<0.001$ \\
\hline \multicolumn{5}{|c|}{ Dispensable amino acid } \\
\hline Ala & 73.3 & 57.6 & 3.0 & 0.004 \\
\hline Asp & 75.5 & 9.8 & 4.1 & $<0.001$ \\
\hline Cys & 66.1 & 5.5 & 4.1 & $<0.001$ \\
\hline Glu & 82.7 & 51.2 & 2.6 & $<0.001$ \\
\hline Gly & 53.3 & 44.0 & 6.0 & 0.300 \\
\hline Pro & 66.3 & 45.0 & 5.6 & 0.023 \\
\hline Ser & 74.6 & 36.3 & 3.2 & $<0.001$ \\
\hline Tyr & 79.9 & 41.0 & 3.9 & $<0.001$ \\
\hline
\end{tabular}

SEM, standard error of the mean.

${ }^{1}$ Each least squares mean represents 6 observations. the indispensable AA determined at the terminal ileum averaged in 75.7 and $52.8 \%$ for SBM and MM, respectively. The AID of all indispensable AA were greater $(\mathrm{p}<0.05)$ in SBM than those in MBM except Gly $(p=0.30)$. This is in agreement with the reported values in NRC (2012) for MM as well as those for MBM (Jørgensen et al., 1984). For the AID of indispensable AA, His was the least digestible AA followed by Thr and Trp. It has been reported that major protein source of MM is collagen (Eastoe and Eastoe, 1954) which is void of Trp. In addition to low concentration of Trp in MM products, it has also been reported that the lowest AID of indispensable AA for MM was Trp (NRC, 2012), which was confirmed in the current study. The lowest AID of indispensable AA was His at $4.3 \%$ and this was lower compared with the values reported in NRC (2012). The reason for this discrepancy is unclear but it might be, at least in part, related to BEL of His. The BEL of His was determined to be $3.10 \mathrm{~g} / \mathrm{kg}$ DMI which is very high compared with values reported in other studies (Kim et al., 2012; Park et al., 2013; Son et al., 2014) and consequently the AID of His for both SBM and MM was considerably less than those reported in NRC (2012). The BEL of Thr also had a similar issue as in His. However, we were unaware of any explanation why the BEL of His and Thr was much greater than the values in the literature.

The respective SID of AA in pigs for SBM, or MM was 86.7, or $65.1 \%$ for Lys, 92.8 , or $79.2 \%$ for Met, and 88.7 , or $65.9 \%$ for Thr (Table 5). The digestibility corrected with BEL of the indispensable AA averaged in 91.7 and $64.6 \%$ for SBM and MM, respectively, which are greater for SBM and less for MM than the average values of the respective ingredients reported in NRC $(2012 ; 87.4 \%$ for SBM and $77.1 \%$ for MM). For the dispensable AA, Pro was the most digestible AA for both SBM (143\%) and MM (81.8\%) whereas Cys $(83.6 \%)$ or Asp $(22.6 \%)$ was the least digestible AA for SBM or MM, respectively. Although the maximum SID cannot exceed $100 \%$, the SID of Pro in SBM exceeded $100 \%$. This indicates that the endogenous level of Pro might be overestimated and this result was in agreement with previous research using an $\mathrm{N}$-free diet for the estimation of the BEL of AA (de Lange et al, 1989; Stein et al., 2005).

In the current study, the concentrations of $\mathrm{CP}$ and AA in MM were greater than those in SBM whereas the AID and SID of all AA in MM were less than the values in SBM. Similar results were reported in the previous study in which MBM was evaluated for 3 different physiological stage groups of pigs (Stein et al., 2001). Cromwell et al. (1991) suggested that the reduction of pig performance with the high level of MM feeding was caused by the excessive $\mathrm{Ca}$ and $\mathrm{P}$ intake, or a reduction in the overall AA balance in the diet.

In conclusion, the results from the present study 
Table 5. Standardized ileal digestibility of crude protein and amino acids in soybean meal and meat meal ${ }^{1,2}$

\begin{tabular}{lcccc}
\hline & \multicolumn{2}{c}{ Test ingredient $(\%)$} & & \\
\cline { 2 - 3 } Item & $\begin{array}{c}\text { Soybean } \\
\text { meal }\end{array}$ & $\begin{array}{c}\text { Meat } \\
\text { meal }\end{array}$ & SEM & p-value \\
Ingredient & & & & \\
Crude protein & 88.8 & 63.5 & 3.0 & $<0.001$ \\
Indispensable amino acid & & & \\
Arg & 94.7 & 80.4 & 2.3 & 0.002 \\
His & 86.4 & 62.3 & 3.4 & 0.001 \\
Ile & 89.0 & 71.4 & 2.2 & $<0.001$ \\
Leu & 88.9 & 72.4 & 2.0 & $<0.001$ \\
Lys & 86.7 & 65.1 & 2.0 & $<0.001$ \\
Met & 92.8 & 79.2 & 1.6 & $<0.001$ \\
Phe & 88.9 & 75.0 & 1.9 & 0.001 \\
Thr & 88.7 & 65.9 & 2.6 & $<0.001$ \\
Trp & 92.3 & 78.5 & 2.8 & 0.002 \\
Val & 88.2 & 70.3 & 2.4 & $<0.001$ \\
Dispensable amino acid & & & & \\
Ala & 86.7 & 65.2 & 3.0 & 0.001 \\
Asp & 83.9 & 22.6 & 4.1 & $<0.001$ \\
Cys & 83.6 & 43.5 & 4.1 & $<0.001$ \\
Glu & 88.7 & 60.3 & 2.6 & $<0.001$ \\
Gly & 89.8 & 53.9 & 6.0 & 0.002 \\
Pro & 143.2 & 81.8 & 5.6 & $<0.001$ \\
Ser & 88.9 & 56.0 & 3.2 & $<0.001$ \\
Tyr & 89.1 & 59.0 & 3.9 & $<0.001$ \\
\hline SEM, & & & &
\end{tabular}

SEM, standard error of the mean.

${ }^{1}$ Each least squares mean represents 6 observations.

${ }^{2}$ Standardized ileal digestibility was calculated by correcting apparent ileal digestibility for the basal ileal endogenous losses. Basal ileal endogenous losses were determined from pigs fed the $\mathrm{N}$-free diet as (g/kg DMI): CP, 29.6; Arg, 1.13; His, 3.10; Ile, 0.61; Leu, 1.14; Lys, 0.83; Met, 0.24; Phe, 0.60; Thr, 1.45; Trp, 0.32; Val, 0.98; Ala, 1.04; Asp 1.83; Cys, 0.64; Glu, 1.97; Gly, 2.75, Pro, 6.74; Ser, 1.38; and Tyr, 0.51.

provided the concentration as well as ileal digestibility of $\mathrm{CP}$ and $\mathrm{AA}$ in SBM and MM and also indicated that the levels of CP and AA in MM were greater than those in SBM whereas the apparent and SID of all AA were less in MM compared with the digestibility of AA in SBM. This information is valuable for accurate swine diet formulations. However, considering that MM or MBM products have a relatively large variation in the nutrient contents (Parson et al., 1997) due to the variation in the raw materials and manufacturing process conditions, further research to determine the variability in the availability of $\mathrm{CP}$ and AA for MM products should be warranted.

\section{ACKNOWLEDGMENTS}

The authors express appreciation to Rural Development Administration (Republic of Korea; PJ907038) for financial support.

\section{REFERENCES}

AAFCO. 2010. Official Publication. Association of American Feed Control Officials Inc., West Lafayette, IN, USA.

AOAC. 2005. Official Methods of Analysis. 18th ed. Association of Official Analytical Chemists, Gaithersburg, MD, USA.

Cromwell, G. L., T. S. Stahly, and H. J. Monegue. 1991. Amino acid supplementation of meat meal in lysine-fortified, cornbased diets for growing-finishing pigs. J. Anim. Sci. 69:48984906.

de Lange, C. F. M., W. C. Saucer, R. Mosenthin, and W. B. Souffrant. 1989. The effect of feeding different protein-free amino acid composition of endogenous protein collected from the distal ileum and feces in pigs. J. Anim. Sci. 67:746-754.

Eastoe, J. E. and B. Eastoe. 1954. The organic constituents of mammalian compact bone. Biochem. J. 57:453-459.

Gottlob, R. O., J. M. DeRouchey, M. D. Tokach, R. D. Goodband, S. S. Dritz, J. L. Nelssen, C. W. Hastad, and D. A. Knabe. 2006 Amino acid and energy digestibility of protein sources for growing pigs. J. Anim. Sci. 84:1396-1402.

Jondreville, C., J. Van den Broecke, F. Gatel, and S. Van Cauwenberghe. 1995. Ileal Digestibility of Amino Acids in Feedstuffs for Pigs. Eurolysine/ITFC publication, Paris, France.

Jørgensen, H., W. C. Sauer, and P. A. Thacker. 1984. Amino acid availabilities in soybean meal, sunflower meal, fish meal and meat and bone meal fed to growing pigs. J. Anim. Sci. 58:926934.

Kim, B. G. and H. H. Stein. 2009. A spreadsheet program for making a balanced Latin square design. Rev. Colomb. Cienc. Pecu. 22:591-596.

Kim, B. G., D. Y. Kil, Y. Zhang, and H. H. Stein. 2012. Concentrations of analyzed or reactive lysine, but not crude protein, may predict the concentration of digestible lysine in distillers dried grains with solubles fed to pigs. J. Anim. Sci. 90:3798-3808.

Mosenthin, R., W. C. Sauer, R. Blank, J. Huisman, and M. Z. Fan. 2000. The concept of digestible amino acids in diet formulation for pigs. Livest. Prod. Sci. 64:265-280.

NRC. 1998. Nutrient Requirements of Swine. 10th ed. National Academy Press, Washington, DC, USA.

NRC. 2012. Nutrient Requirements of Swine. 11th ed. National Academy Press, Washington, DC, USA.

Park, C. S., S. I. Oh, and B. G. Kim. 2013. Prediction of basal endogenous losses of amino acids based on body weight and feed intake in pigs fed nitrogen-free diets. Rev. Colomb. Cienc. Pecu. 26:186-192.

Parsons, C. M., F. Castanon, and Y. Han. 1997. Protein and amino acid quality of meat and bone meal. Poult. Sci. 76:361-368.

Sauer, W. C. and L. Ozimek. 1986. Digestibility of amino acids in swine: Results and their practical applications. A review. Livest. Prod. Sci. 15:367-388.

Son, A. R., Y. Hyun, J. K. Htoo, and B. G. Kim. 2014. Amino acid digestibility in copra expellers and palm kernel expellers by growing pigs. Anim. Feed Sci. Technol. 187:91-97.

Stein, H. H., B. Sève, M. F. Fuller, P. J. Moughan, and C. F. M. de Lange. 2007. Invited review: Amino acid bioavailability and digestibility in pig feed ingredients: Terminology and application. J. Anim. Sci. 85:172-180. 
Stein, H. H., C. F. Shipley, and R. A. Easter. 1998. Technical note: a technique for inserting a T-cannula into the distal ileum of pregnant sows. J. Anim. Sci. 76:1433-1436.

Stein, H. H., C. Pedersen, A. R. Wirt, and R. A. Bohlke. 2005. Additivity of values for apparent and standardized ileal digestibility of amino acids in mixed fed to growing pigs. J. Anim. Sci. 83:2387-2395.
Stein, H. H., S. W. Kim, T. T. Nielsen, and R. A. Easter. 2001. Standardized ileal protein and amino acid digestibility by growing pigs and sows. J. Anim. Sci. 79:2113-2122.

Traylor, S. L., G. L. Cromwell, and M. D. Lindemann. 2005. Bioavailability of phosphorus in meat and bone meal for swine. J. Anim. Sci. 83:1054-1061.

Wang, X. and C. M. Parsons. 1998. Effect of raw material source, processing system, and processing temperatures on amino acid digestibility of meat and bone meals. Poult. Sci. 77:834-841. 